\title{
EXPERT VALIDITY ON THE DEVELOPMENT OF PROJECT \& WORK BASED LEARNING MODELS IN ARCHITECTURAL DESIGN STUDIO
}

\author{
${ }^{1}$ Irnawati Siregar, Jalius Jama ${ }^{2}$, Fahmi Rizal ${ }^{3}$ \\ Doctoral Program in Technology and Vocational Education \\ Universitas Negeri Padang \\ Email: siregar.irna@yahoo.co.id
}

\begin{abstract}
This research was conducted to answer the level of validity of the project \& work based learning model collaboration in learning, especially the architecture design studio as the object of this research. The problem of the gap between the needs of the architectural industry and the outcome of the architectural study program is now a polemic for architectural study programs in general. The development model resulting from this study has been validated by experts in their fields.

Tests carried out are: test validity, practicality, and effectiveness using V Aiken data analysis. Hypothesis testing using independent t-test. Validity test shows a fairly high interpretation (valid), practicality test shows very practical interpretation, and effectiveness test shows very effective interpretation.

This study produces a project \& work based learning model in studio design subjects on all aspects of assessment categorized as valid, for practicality to have practical practices. Assessment of effectiveness in the three aspects of the domain: affective, cognitive, and psychomotor is very effective and can improve learning outcomes and student work.
\end{abstract}

Keywords: Expert validity, reseach development, project based learning, work based learning, pembelajaran studio perancangan arsitektur.

\section{Introduction.}

The adoption of the ASEAN Economic Community (MEA) at the end of 2015 has implications in the form of the high demand for competent and skilled workers in their fields. This demand arises from various industries and markets. The logical impact of the workforce from various Southeast Asian regions will be competing with each other for employment, and only workers who have high competencies have wider opportunities to join and benefit from the MEA. The presence of the MEA is a global challenge in front of the eyes of the Indonesian people.

In connection with the implementation of the AEC, research conducted by Keliat et.al (2013) on mapping Indonesia's skilled labor and ASEAN service liberalization, found findings that in general, in terms of quantity of human resources, almost all sectors (engineers, architects, nurses, doctors , dentists, and accountants) have a shortage of professionals in the field. Research Titik. H (2015), the importance of 
cooperation and synergy of universities with the world of work and industry both at national and international levels to face the gap between the demand and the availability of educated workers. Mapping in the field of architectural education found that graduates of architectural study programs do not have sufficient qualifications to compete in the world of work. According to Tri Harso Karyono (2012), students are less prepared to enter the workforce because of lack of skilled students in architectural practice. This is due to the lack of student schedules in the practice of architectural architecture, especially in the architectural design studio courses.

In addition, methods and learning materials in the architectural study program have not fully been able to overcome the relevance of education to the world of work. Research conducted by Ashaf. M. 2017, the right teaching and learning strategy for the architectural design process in the pedagogic design studio. Research conducted by Elin S.M. et al, found that the design creativity of students at $43.76 \%$ was determined by the experience of architecture and $56.24 \%$ determined by other factors. Review pembelajaran arsitektur. Irna. S (2015), this review of architectural design studio education and learning studies aims to examine research articles published between January 2010 and April 2015 sources from data using the Science Direct online database, found continuing education and surrounding support that allows students to be more creative with educational skills current and teaching strategies for educators.

Based on the results of pre-research observations conducted on internship and work students that learning in Higher Education is not fully used in the world of work, because the competencies expected in the world of work are different from those given in college. The expected competence of the world of work at this time is the industrial revolution 4.0 in general is known as a change in work methods that focus on data management (big data), industrial work systems through technological advances, communication and work efficiency improvements related to human interaction. In the field of competency architecture students are expected to be able to do work with categories having design experience as real architectural works in accordance with 13 items of competence issued by the Indonesian Architects Association (IAI), and have experience in architectural practice.

Other indications that make students unable to compete globally, because there is still a lack of application of 37 items of competence issued by the Union Internationale of Architectes (UIA). While in international competition, students have been able to do the 37 items.

Based on the results of observations and interviews with student interns and work, it can be concluded that the importance of improving the learning system in the study program of architecture, and human resources (HR) involved with learning. The learning system that needs to be improved is on subjects that are in direct contact with the work system, namely: architectural design studio courses. As for HR, namely: by presenting practitioners who directly provide examples according to the world of work. The learning model that can overcome these problems is the project $\&$ work based learning model in the architecture design studio learning.

\section{Method}


The development model in this study uses the stages of design and development research $(\mathrm{R} \& \mathrm{D})$. This study adopted a number of steps for the development of Borg \& Gall (2003: 569), where according to Borg \& Gall, development research in the field of education had steps taken by researchers so that the products designed had the feasibility.

Sukmadinata (2010) explains "If the ten steps of research and development are followed correctly, it will be able to produce an accountable education product". These steps are not standard things that must be followed, the steps taken can be adjusted to the needs of researchers.

According to research Sugiyono (2012: 409), development research is the steps that must be followed to produce development research methods in the form of: products include potential and problem stages, data collection, product design, design validation, product design revision, product testing, product revision , usage testing, product revision, and mass production that can function in the wider community.

The presentation of procedural steps from the development of expert validity project \& work based learning models in architectural design studio subjects can be explained in Figure 2.1. The results of the Focus Group Discussion, there was input from the expert for all products, then product improvements were made, after product repairs were carried out product testing.

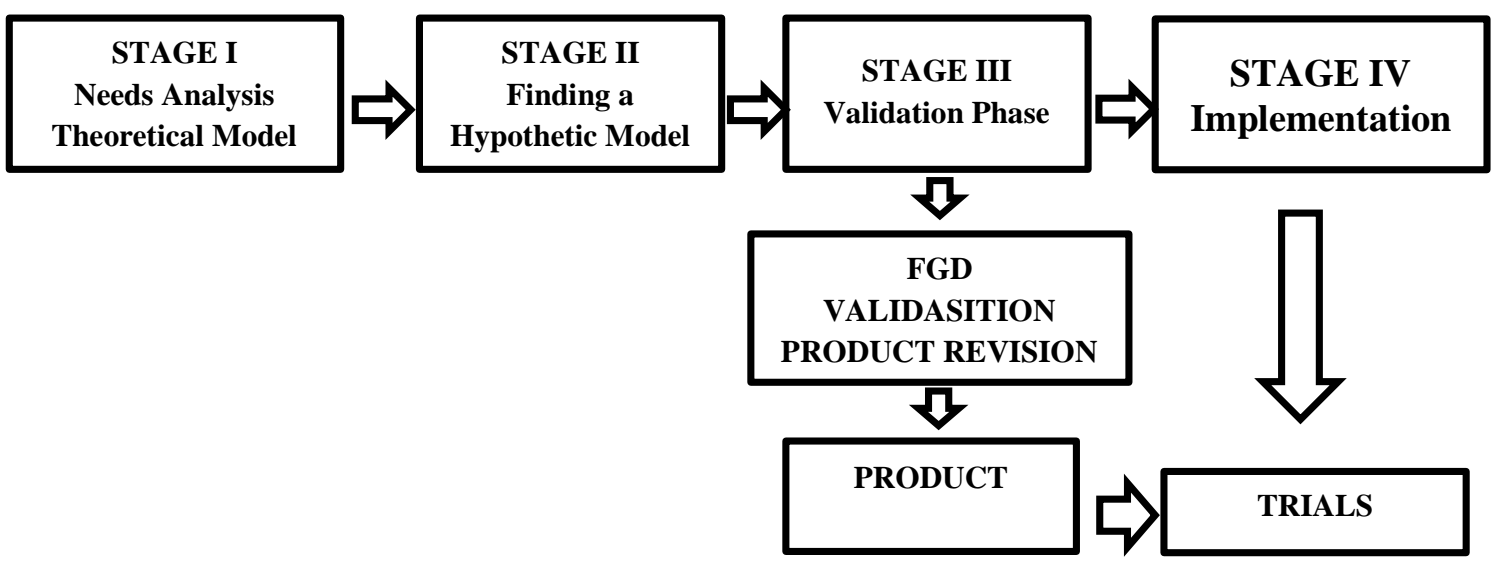

Gambar 2.1. Alur Expert Validity Pengembangan Model Project \& Work Based Learning

Test project \& work based learning models in studio design courses on architecture carried out in the Architecture Study Program of Ekasakti University in Padang and in the Bung Hatta University Architecture study program. The test subjects in the research project \& work based learning model were divided according to the stages of the trial that had been designed, namely: (1) the subject for expert testing for contract testing and content, (2) limited test subjects, and (3) subjects for expand / field trials.

The subject of expert testing for construct validation of the experts involved in the testing of construct validation phase of the project \& work based learning model 
are experts in technology and vocational education (vocational education), professional experts in architecture, experts in the field of architectural design studio learning, experts in the field evaluation of learning, as well as experts in the field of Indonesian language.

The subject of expert testing for contract validation, the expert involved in the testing of construct validation phase of the project \& work based learning model is an expert in technology and vocational education (vocational education), expert in the field of professional architecture, expert in the field of studio architecture design the field of learning evaluation, as well as experts in the field of Indonesian language.

The subject of the field trial was extended to the research project model \& work based learning carried out to users, namely: lecturers and students, at this stage a trial was conducted representing students who took the Architecture Design Studio course in the January-June 2018 semester, as many as 15 students.

\section{Result and Discussion.}

\subsection{Validity Test}

Validation is carried out on the aspect of the feasibility of the contents of the instrument on product validity, showing the value of $\mathrm{V}=0.62$, meaning $>0.60$, then the value of V Aiken is declared valid. According to Azwar (2013; 123), an assessment with a $\mathrm{V}$ Aiken validity level obtained greater than 0.60 is interpreted to be high enough (valid). The results of the validation of the instrument feasibility aspects of the instrument language obtained $\mathrm{V}=0.63$ categorized as valid, and validation of the eligibility of the graphical aspects obtained $\mathrm{V}=0.63$ is categorized as valid.

The results of the validation of the learning model book, which consists of aspects: rational model, supporting theory of the model, model syntax, social system, reaction principle, model support system, and instructional impact and model accompaniment, show the overall $\mathrm{V}$ Aiken value with a value of $\mathrm{V}=0.84$, means $>0.60$, then the value of $\mathrm{V}$ Aikan in the project \& work based learning model book is declared valid.

The results of the module validation teach the project \& work based learning model to assess the feasibility component of the content of the teaching module in points 1 to 9 obtained the value of $\mathrm{V}=0.91$ which means $>0.60$ is interpreted valid. For the feasibility component of learning quality items 10 to 13 , $\mathrm{V}=0.86$ are also declared valid. Component stand alone rating 14 to $15, \mathrm{~V}=0.83$ is also valid. For adaptive components items 16 to $17, \mathrm{~V}=0.88$ is declared valid. The assessment of the user friendly component of items 18 to $21, \mathrm{~V}=0.86$ is declared valid. For graphical components grains 22 to $30, \mathrm{~V}=0.87$ is declared valid. Assessment of language components items 31 to $39, \mathrm{~V}=0.85$ is declared valid. For assessment of the feasibility aspects of evaluation items 40 to $45, \mathrm{~V}=$ 0.88 is also valid. 
The results of the validation of the lecturer performance manual in the project \& work based learning model for the feasibility of the front page components in points 1 to $5, \mathrm{~V}=0.79>0.60$ are interpreted valid. For writing format components in points 6 to $8, \mathrm{~V}=0.82$ is declared valid. Assessment of language use components in points 9 to $18, \mathrm{~V}=0.79$ is also valid. For the table of contents component in items 19 to $20, \mathrm{~V}=0.83$ is declared valid. Assessment of the preliminary components in items 21 to $27, \mathrm{~V}=0.79$ is declared valid. For the component contents in items 28 to $37, \mathrm{~V}=0.83$ is declared valid. Evaluation of evaluation components in items 38 to $45, \mathrm{~V}=0.79$ is declared valid.

\subsection{Practicality Test}

The results of the product practicality test of the expert respondents on the product model of project \& work based learning from several aspects, on the component of the feasibility of the content of the instrument, at 1 to $5, \mathrm{~V}=0.60$ is interpreted practically. For the instrument language feasibility component, in points 6 to $10, \mathrm{~V}=0.65$ is stated practical. Assessment for the component of the eligibility aspect of graphics, in points 11 to $18, \mathrm{~V}=0.60$ is stated practical.

Lecturer respondent's practicality test for the project \& work based learning model product for the feasibility component of the book model aspect, in items 1 to $12, \mathrm{~V}=0.81$ which means $>0.60$ is interpreted practically. The assessment for the feasibility component of the teaching module aspects of the book, in points 13 to $22, \mathrm{~V}=0.82$ is categorized as practical. For the feasibility component of the aspect of lecturer performance manual (PKD), items 23 to 31, $\mathrm{V}=0.83$ are stated to be practical

Practicality test of student respondents on project \& work based learning model products for the feasibility component of the learning module aspects, in points 1 to $9, \mathrm{~V}=0.86>0.60$ is very practical. Assessment for the feasibility component of the learning module aspects, in points 1 to $9, \mathrm{~V}=0.86>0.60$ is interpreted very practical. For the feasibility component of the aspects of student work guidelines at 10 to $19, \mathrm{~V}=0.87$ with a very practical category. This practicality test was carried out on 15 student respondents.

\subsection{Effectiveness Test}

The effectiveness test of this model was tested by students of the experimental group, amounting to 15 students with a trial schedule of 21 February 2018 - 29 June 2018. The results of the trials were compared with the control group of 15 students with the same schedule. The results of the evaluation between the treatment group and the control group used values of learning outcomes from aspects of the Apective, Cognitive, and Psychomotor domains.

The results of the processing of the statistical data on the objective domain of the treatment group Table 4.1. The average score for all aspects consisted of: the attitude aspect of accepting learning, answering attitudes, judging attitudes, organizing attitudes, and forming patterns of work activities, with mean 83.93, median 82.00, mode 79, and standard deviation 5,230 
Table 4.1. Data Frequency Distribution of Apective Field Treatment Group Statistics

\begin{tabular}{|c|c|c|c|c|c|c|c|}
\hline & & $\begin{array}{c}\text { Sikap } \\
\text { Menerima }\end{array}$ & $\begin{array}{l}\text { Sikap } \\
\text { Menjawab }\end{array}$ & Sikap Menilai & $\begin{array}{l}\text { Sikap } \\
\text { Mengorganis } \\
\text { asikan }\end{array}$ & $\begin{array}{c}\text { Pembentukan } \\
\text { Pola Kegiatan } \\
\text { Bekerja }\end{array}$ & Skor \\
\hline \multirow[t]{2}{*}{$N$} & Valid & 15 & 15 & 15 & 15 & 15 & 15 \\
\hline & Missing & 0 & 0 & 0 & 0 & 0 & 0 \\
\hline \multicolumn{2}{|c|}{ Mean } & 84.27 & 83.07 & 81.67 & 83.20 & 87.07 & 83.93 \\
\hline \multicolumn{2}{|c|}{ Median } & 85.00 & 80.00 & 80.00 & 82.00 & 87.00 & 82.00 \\
\hline \multicolumn{2}{|c|}{ Mode } & 80 & 80 & 75 & 80 & 80 & $79=$ \\
\hline \multicolumn{2}{|c|}{ Std. Deviation } & 5.994 & 5.535 & 7.537 & 4.229 & 6.204 & 5.230 \\
\hline \multicolumn{2}{|c|}{ Minimum } & 75 & 75 & 70 & 78 & 78 & 78 \\
\hline \multicolumn{2}{|c|}{ Maximum } & 95 & 95 & 95 & 90 & 96 & 93 \\
\hline \multicolumn{2}{|c|}{ Sum } & 1264 & 1246 & 1225 & 1248 & 1306 & 1259 \\
\hline
\end{tabular}

a. Multiple modes exist. The smallest value is shown

Table 4.2. Data Frequency Distribution of Treatment Group Cognitive Spheres

\begin{tabular}{|c|c|c|}
\hline$N$ & Valid & 15 \\
\hline & Missing & 15 \\
\hline $\mathrm{Me}$ & & 83.40 \\
\hline & & 82.00 \\
\hline & & 5.289 \\
\hline & & 75 \\
\hline & & 94 \\
\hline Sur & & 1251 \\
\hline
\end{tabular}

Cognitive domain statistical data processing in the treatment group Table 4.3, on all learning indicators: PI, PII, PIII, PIV, PV, PVI, PVII, PVIII, PIX, PX, PXI, PXII, PXIII, all indicators achieved with mean scores $>80$, median> 80, mode $>75$, and standard deviation $>4,719$.

Table 4.3. Group Cognitive Data Frequency Distribution Each Treatment Indicator

Statistics

\begin{tabular}{|l|r|r|r|r|r|r|r|r|r|r|r|r|r|}
\hline & \multicolumn{1}{|c|}{ P I } & \multicolumn{1}{|c|}{ P II } & P III & P IV & P V & P VI & P VII & P VIII & P IX & P X & P XI & P XII & P XIII \\
\hline N Valid & 15 & 15 & 15 & 15 & 15 & 15 & 15 & 15 & 15 & 15 & 15 & 15 & 15 \\
\multicolumn{1}{r|}{ Missing } & 15 & 15 & 15 & 15 & 15 & 15 & 15 & 15 & 15 & 15 & 15 & 15 & 15 \\
Mean & 83.73 & 81.87 & 82.73 & 85.20 & 82.53 & 84.53 & 84.00 & 83.20 & 81.67 & 84.20 & 83.13 & 83.47 & 83.73 \\
Median & 85.00 & 82.00 & 80.00 & 86.00 & 83.00 & 86.00 & 85.00 & 85.00 & 80.00 & 85.00 & 80.00 & 80.00 & 83.00 \\
Mode & $75^{\mathrm{a}}$ & $75^{\mathrm{a}}$ & 80 & $85^{\mathrm{a}}$ & $80^{\mathrm{a}}$ & 86 & 85 & 85 & 80 & $77^{\mathrm{a}}$ & 80 & 80 & 80 \\
Std. Deviation & 7.723 & 6.266 & 5.750 & 5.031 & 4.719 & 6.266 & 6.719 & 6.450 & 7.148 & 5.772 & 7.019 & 6.906 & 6.147 \\
Minimum & 70 & 70 & 75 & 72 & 75 & 70 & 70 & 70 & 70 & 77 & 72 & 72 & 75 \\
Maximum & 95 & 90 & 93 & 92 & 90 & 94 & 95 & 95 & 93 & 94 & 96 & 95 & 95 \\
Sum & 1256 & 1228 & 1241 & 1278 & 1238 & 1268 & 1260 & 1248 & 1225 & 1263 & 1247 & 1252 & 1256 \\
\hline
\end{tabular}

a. Multiple modes exist. The smallest value is shown

Statistical data processing in Table 4.4, frequency distribution of the Cognitive realm of the control group with a mean score of 67.20 , median 67.00 , mode 67.00 , and standard deviation of 1.821 .

Table 4.4. Data Frequency Distribution Cognitive Sphere Control Group 


\begin{tabular}{|l|r|}
\hline \multicolumn{1}{|c|}{$\quad$ Valid } & 15 \\
\multicolumn{1}{|c|}{ Missing } & 0 \\
Mean & 67.20 \\
Median & 67.00 \\
Mode & 67 \\
Std. Deviation & 1.821 \\
Minimum & 65 \\
Maximum & 71 \\
Sum & 1008 \\
\hline
\end{tabular}

The results of statistical data processing on the Cognitive realm of the control group Table 4.5, it can be concluded that all indicators were not achieved with mean scores $<80$, and medians $<80$, and mode $<75$, for standard deviations exceeding treatment groups at T5, T9, 12, and T13> 4,719. Table 4.15. Cognitive Data Frequency Distribution Control Group Each Indicator.

Table 4.5 Frequency Distribution of Group Psychomotor Data Each Treatment Indicator

\begin{tabular}{|c|c|c|c|c|c|c|c|c|c|c|c|c|c|c|}
\hline \multicolumn{15}{|c|}{ Statistics } \\
\hline & & $\mathrm{T} 1$ & $\mathrm{~T} 2$ & $\mathrm{~T} 3$ & $\mathrm{~T} 4$ & $\mathrm{~T} 5$ & T6 & $\mathrm{T7}$ & T8 & T9 & $\mathrm{T} 10$ & $\mathrm{~T} 11$ & $\mathrm{~T} 12$ & $\mathrm{~T} 13$ \\
\hline \multirow[t]{2}{*}{ N } & Valid & 15 & 15 & 15 & 15 & 15 & 15 & 15 & 15 & 15 & 15 & 15 & 15 & 15 \\
\hline & Missing & 0 & 0 & 0 & 0 & 0 & 0 & 0 & 0 & 0 & 0 & 0 & 0 & 0 \\
\hline \multicolumn{2}{|c|}{ Mean } & 69.33 & 63.00 & 69.33 & 63.00 & 67.00 & 67.00 & 65.00 & 69.33 & 67.00 & 69.33 & 69.33 & 67.00 & 67.00 \\
\hline \multicolumn{2}{|c|}{ Median } & 70.00 & 65.00 & 70.00 & 65.00 & 65.00 & 65.00 & 65.00 & 70.00 & 65.00 & 70.00 & 70.00 & 65.00 & 65.00 \\
\hline \multicolumn{2}{|c|}{ Mode } & 70 & 65 & 70 & 65 & 65 & 65 & 65 & 70 & 65 & 70 & 70 & 65 & 65 \\
\hline \multicolumn{2}{|c|}{ Std. Deviation } & 3.716 & 2.535 & 3.716 & 2.535 & 2.535 & 5.606 & .000 & 3.716 & 5.606 & 3.716 & 3.716 & 5.606 & 5.606 \\
\hline \multicolumn{2}{|c|}{ Minimum } & 65 & 60 & 65 & 60 & 65 & 65 & 65 & 65 & 65 & 65 & 65 & 65 & 65 \\
\hline \multicolumn{2}{|c|}{ Maximum } & 75 & 65 & 75 & 65 & 70 & 85 & 65 & 75 & 85 & 75 & 75 & 85 & 85 \\
\hline \multicolumn{2}{|c|}{ Sum } & 1040 & 945 & 1040 & 945 & 1005 & 1005 & 975 & 1040 & 1005 & 1040 & 1040 & 1005 & 1005 \\
\hline
\end{tabular}

indicators were achieved with a mean score of $<84.00$, and a median $<85.00$, as well as a mode $<80$, and for standard deviations between $2.6-6.7$.

Table 4.6. Frequency Distribution of Group Psychomotor Data Each Treatment Indicator

\section{Statistics}

\begin{tabular}{|l|r|r|r|r|r|r|r|r|}
\hline & \multicolumn{1}{|c|}{$\mathrm{P} 1$} & \multicolumn{1}{c|}{$\mathrm{P} 2$} & $\mathrm{P} 3$ & $\mathrm{P} 4$ & $\mathrm{P} 5$ & \multicolumn{1}{c|}{$\mathrm{P} 6$} & \multicolumn{1}{c|}{$\mathrm{P} 7$} & \multicolumn{1}{c|}{ TOTAL } \\
\hline $\mathrm{N}$ Valid & 15 & 15 & 15 & 15 & 15 & 15 & 15 & 15 \\
\multicolumn{1}{|c}{ Missing } & 0 & 0 & 0 & 0 & 0 & 0 & 0 & 0 \\
Mean & 84.80 & 84.67 & 85.33 & 89.60 & 90.13 & 90.87 & 89.47 & 88.00 \\
Median & 85.00 & 85.00 & 87.00 & 90.00 & 90.00 & 90.00 & 90.00 & 88.00 \\
Mode & 80 & 80 & 85 & 90 & 90 & 90 & 90 & 87 \\
Std. Deviation & 6.784 & 5.010 & 4.515 & 3.562 & 2.615 & 3.461 & 4.138 & 3.443 \\
Minimum & 75 & 78 & 75 & 83 & 85 & 85 & 78 & 82 \\
Maximum & 95 & 95 & 90 & 95 & 95 & 95 & 95 & 94 \\
Sum & 1272 & 1270 & 1280 & 1344 & 1352 & 1363 & 1342 & 1320 \\
\hline
\end{tabular}

a. Multiple modes exist. The smallest value is shown

The results of statistical processing in Table 4.7 are the Psychomotor domain data frequency distribution of the control group with a mean score of 66.00 , median 66.00, mode 66, and standard deviation of 1.773 . 
Table 4.7. Psychomotor Domain Data Frequency Distribution Control Group

\begin{tabular}{|c|c|c|}
\hline \multicolumn{3}{|c|}{ Statistics } \\
\hline & & \\
\hline $\mathrm{N}$ & Valid & 15 \\
\hline & Missing & 0 \\
\hline $\mathrm{Me}$ & & 66.00 \\
\hline & & 66.00 \\
\hline Mo & & 66 \\
\hline & iation & 1.773 \\
\hline & & 63 \\
\hline & & 69 \\
\hline Sur & & 990 \\
\hline
\end{tabular}

Statistical data processing results on the Psychomotor domain of the control group Table 4.8, showing for all indicators T1 - T13, it can be concluded that almost all indicators have mean scores of 66.00, and medians of 66.00, and mode 66, and for standard deviations of 1.773 .

Table 4.8. Psychomotor Data Analysis Control Group Each Indicator

Statistics

\begin{tabular}{|c|c|c|c|c|c|c|c|c|c|c|c|c|c|c|c|}
\hline & & $\mathrm{T} 1$ & $\mathrm{~T} 2$ & $\mathrm{~T} 3$ & $\mathrm{~T} 4$ & T5 & T6 & $\mathrm{T} 7$ & T8 & $\mathrm{Tg}$ & $\mathrm{T} 10$ & $\mathrm{~T} 11$ & $\mathrm{~T} 12$ & $\mathrm{~T} 13$ & TOTAL \\
\hline$N$ & Valid & 15 & 15 & 15 & 15 & 15 & 15 & 15 & 15 & 15 & 15 & 15 & 15 & 15 & 15 \\
\hline & Missing & 0 & 0 & 0 & 0 & 0 & 0 & 0 & 0 & 0 & 0 & 0 & 0 & 0 & 0 \\
\hline Me & & 64.33 & 65.00 & 67.33 & 59.67 & 63.73 & 65.00 & 65.00 & 65.00 & 65.00 & 65.00 & 81.13 & 65.00 & 67.00 & 66.00 \\
\hline & & 65.00 & 65.00 & 65.00 & 60.00 & 65.00 & 65.00 & 65.00 & 65.00 & 65.00 & 65.00 & 81.00 & 65.00 & 65.00 & 66.00 \\
\hline Mo & & 70 & 65 & 65 & 50 & 60 & 65 & 65 & 65 & 65 & 65 & $67^{2}$ & 65 & 65 & 66 \\
\hline & viation & 5.627 & .000 & 4.169 & 8.550 & 6.419 & .000 & .000 & .000 & .000 & .000 & 10.006 & .000 & 5.606 & 1.773 \\
\hline & & 55 & 65 & 60 & 50 & 50 & 65 & 65 & 65 & 65 & 65 & 67 & 65 & 65 & 63 \\
\hline & & 70 & 65 & 75 & 70 & 75 & 65 & 65 & 65 & 65 & 65 & 97 & 65 & 85 & 69 \\
\hline Sul & & 965 & 975 & 1010 & 895 & 956 & 975 & 975 & 975 & 975 & 975 & 1217 & 975 & 1005 & 990 \\
\hline
\end{tabular}

a. Multiple modes exist. The smallestvalue is shown

\section{Discussion}

5. Implications

6. Recommendations

7. Limitations

8. Future research opportunities.

9. Conclusion

The results of the analysis of product validity and the support of the project \& work based learning model in the studio architecture design course, in all aspects of assessment categorized as valid, for practicality analysis, the product has a high practicality with a practical category. To assess the effectiveness of the three aspects of the affective, cognitive, and psychomotor domains, it is very effective and influences student learning outcomes. 


\section{Thank-you note}

Thanks to all those who have helped this research, especially:

Mentor and Judgment expert: Prof. Jalius Jama, M.Ed, Dr. Fahmi Rizal, M.Pd., MT, Prof. Dr. Nizwardi Jalinus, M.Ed, Prof. Dr. Ellizar, M.Pd, Dr. Rudi Chandra, Dr. Ridwan, Dra. Emidar, M.Pd, Ir. Syamsul Asri, Ph.D, Ir. Donni Andrianto, IAI, Ir Rasyidin, MT, Dian Wahyoni DF, ST., MT, Ir. Darmawis

\section{REFERENCES}

Asosiasi Pendidikan Arsitektur Indonesia. (2010). Kompetensi Pendidikan Tinggi Arsitektur di Indonesia.

Azwar. (2013). Tes Prestasi: Fungsi dan Pengembangan Pengukuran Prestasi Belajar. Yogyakarta: Pustaka Pelajar.

Elin S.M. et al. (2013). Jurnal INVOTEC (Innovation of Vocational and Technology Education). Jurnal INVOTEC (Innovation of Vocational and Technology Education), IX(1).

Gall, M. D and Borg, W. R. (2003). Educational research: an introduction (7th ed.). New York: Longman, Inc.

Indonesia, I. A. (2001). Buku Panduan IAI: Pedoman Hubungan Kerja Antara Arsitek Dengan Pengguna Jasa. Jakarta: Ikatan Arsitek Indonesia.

Irna. S. (2015). Review Pendidikan dan Pembelajaran di Studio Desain Arsitektur. In Konferensi Internasional Pendidikan Global III.

Karyono, T. H. (2012). Permasalahan dan Strategi Pembelajaran Matakuliah Perancangan Arsitektur. Retrieved from https://www.researchgate.net/profile/Tri_Karyono/publication/305189577

Keliat et.al. (2013). Pemetaan Tenaga Terampil Indonesia dan Liberalisasi Jasa ASEAN. Jakarta.

Pramudyo, A. (2014). Mempersiapkan Sumber Daya Manusia Indonesia Dalam Menghadapi Masyarakat Ekonomi ASEAN Tahun 2015. Jurnal JBMA, II.

Soliman, A. M. (2017). Frontiers of Architectural Research 6.

Sugiono. (2012). Metode Penelitian, Kuatitatif, Kualitatif dan R\&D. Bandung: Alfabeta.

Sukmadinata, N. S. (2008). Metode Penelitian Pendidikan. Bandung: PT Remaja Rosdakarya.

Titik. H. (2015). No Title. Jurnal Kependudukan Indonesia, 10(1), 53-64.

UIA/UNESCO. (2012). Charter for Architectural Education. Retrieved from http://www.unesco.org/ most/uiachart.htm 